\title{
CD Markers in Monocyte Subpopulation in Egyptian Children and adults with Chronic Renal Failure
}

\author{
Tarek Zebeeb', Hanan H. Fuaad², Osama F. Shalan'1, Randa M. Talaat' \\ ${ }^{1}$ Department of Molecular Diagnostics, Genetic Engineering and Biotechnology \\ Research Institute (GEBRI), University of Sadat city, Menofia, Egypt \\ ${ }^{2}$ Biochemistry Department, Faculty of Medicine, Cairo University
}

Corresponding author: Tarek Zebeeb_Ｅmail:dr_tarekzbeeb@yahoo.com

\begin{abstract}
Background: Chronic kidney disease is a worldwide public health problem and is now recognized as a common condition that is associated with an increased risk of cardiovascular disease and chronic renal failure (Bash LD et al.,2009) .Chronic kidney disease define as either kidney damage or a decrease kidney glomerular filteration rate $(\mathrm{G}$ F R) of less than $60 \mathrm{ml} / \mathrm{min} / 1.73 \mathrm{~m} 2$ for three or more months (Choi AI et al., 2009), Whatever the underlying etiology, the destruction of renal mass with irreversible sclerosis and loss of nephrons leads to a progressive decline in (G F R).

Methods: Immunological measurements of monocyte sub population (CD Markers) CD4 and CD56 for 48 Patients were divided to 4 groups. Tow control groups, One of 12 healthy adults and other one for 12 healthy Children. Tow Patients group, one of 12 Egyptian adults of high serum creatnine concentration under renal dialysis and last group of 12Egyptian children of high serum creatinine concentration under renal dialysis. In this work we investigate CD 4 and CD56 in Monocyte sub population in Egyptian adults and children at end stage renal disease under renal dialysis to evaluate the immune response. Results: In this study we found that CD4 and CD56 is decreased in most Egyptian adults and children of high serum creatinine concentration under renal dialysis compared to healthy control groups where $(\mathrm{P}<0.05)$. Conclusion: Altered immune function in patients with renal failure results in both susceptibility to infection and increased inflammatory response. Our study reached that Monocyte sub population (CD Markers) CD4 and CD56in Egyptian children and adults are decreased in most tested patients with chronic renal failure (at End Stage Renal Disease) under renal dialysis.
\end{abstract}

Key words: CD4, CD56, CD Markers, Egyptian patients

\section{INTRODUCTION}

Risk factors for CKD (Chronic Kidney Disease) include genetic or sociodemographic predisposition, or the presence of diseases which can initiate and propagate kidney disease. Kidney failure is the end-stage of CKD and is defined as severely reduced kidney function or treatment with dialysis. The term "end-stage renal disease" (ESRD) generally refers to chronic kidney failure treated with either dialysis or transplantation. Acute kidney injury (AKI) may complicate CKD and hasten its progression (Hsu CY et al., 2008 ; James MT et al.,2010). The cluster of differentiation (cluster of designation or 
Classification Determinant) (often abbreviated as CD) is a protocol used for the identification and investigation of cell surface molecules providing targets for immunophenotyping (Chan, J. K. C. 1988) of cells .In terms of physiology, $\mathrm{CD}$ molecules can act in numerous ways, often acting as receptors or ligands (the molecule that activates a receptor) important to the cell. A signal cascade is usually initiated, altering the behavior of the cell. Some CD proteins do not play a role in cell signaling, but have other functions, such as cell adhesion. CD for humans is numbered up to 350 most recently (HCDM 2009; Zola H 2006) .

\section{PATIENTS\&METHODS}

Immunological measurements of monocyte sub population (CD Markers) CD4 and CD56 carried out for 48 Patients. All samples included in this study collected during the time period from year 2010 to 2012 and selected from department of renal dialysis - Menofia University Hospital. The age of patients ranged between 8-50 years. Patients divided into four groups Group 1, Group 2, Group 3 and Group 4.

Inclusion Criteria: Children from 8 years and adults to 50 years old, Both gender, under renal dialysis.

\section{Exclusion Criteria}

Patient who receive chemotherapy.

Patients were subjected to the following routine laboratory investigations that include; Serum creatinine, Urea, K, Na,
$\mathrm{Ca}$ and blood Heamoglobin. Investigation of CD Markers CD4 and CD56, Samples were processed on FCM and gating was done on Lymphocytes and Monocytes cell population based on its forward and side scatter properties. Immunophenotyping on peripheral blood samples, on flow cytometry (Beckman Coulter) using monoclonal for CD4 \& CD 56 (BioRad Company).

\section{RSULTS}

The patients were divided into Four groups:-

Group1: act as control patient include 12 (adults) with normal serum creatinine concentration and not suffering from renal diseases.

Group 2: act as control patient include 12 (children) with normal serum creatinine concentration and not suffering from renal diseases.

Group 3: patient with renal dialysis include 12 (Adults) with high serum creatinine conc.

Group 4: patient with renal dialysis include 12 (Children) with high serum creatinine concentration.

A total of 24 Patient with chronic renal Failure were reviewed and approved the current study. Serum estimation of creatinine, urea, $\mathrm{K}, \mathrm{Na}$, and $\mathrm{Ca}$ level were done, Peripheral Blood estimation of CD4 and CD56. 
*Table (1) Comparison between group 1 and group 3as regarding to Creatinine\& urea.

\begin{tabular}{||l|c|c|c|c||}
\hline Variables & $\begin{array}{c}\text { Group 1 } \\
(\mathrm{n}=12) \\
(\text { mean } \pm \mathrm{SD})\end{array}$ & $\begin{array}{c}\text { Group 3 } \\
(\mathrm{n}=12) \\
(\text { mean } \pm \mathrm{SD})\end{array}$ & t- value & $\mathrm{p}$ - value \\
\hline \hline Creatinine & $0.86 \pm 0.15$ & $7.12 \pm 2.40$ & 9.009 & $<0.001 *$ \\
\hline Urea & $23.17 \pm 2.25$ & $90.25 \pm 30.08$ & 7.704 & $<0.001^{*}$ \\
\hline
\end{tabular}

$* \mathrm{P}<0.05$ is considered Significant

Table (1) shows highly statistical significant difference between studied groups as regards serum creatinine \& Urea.

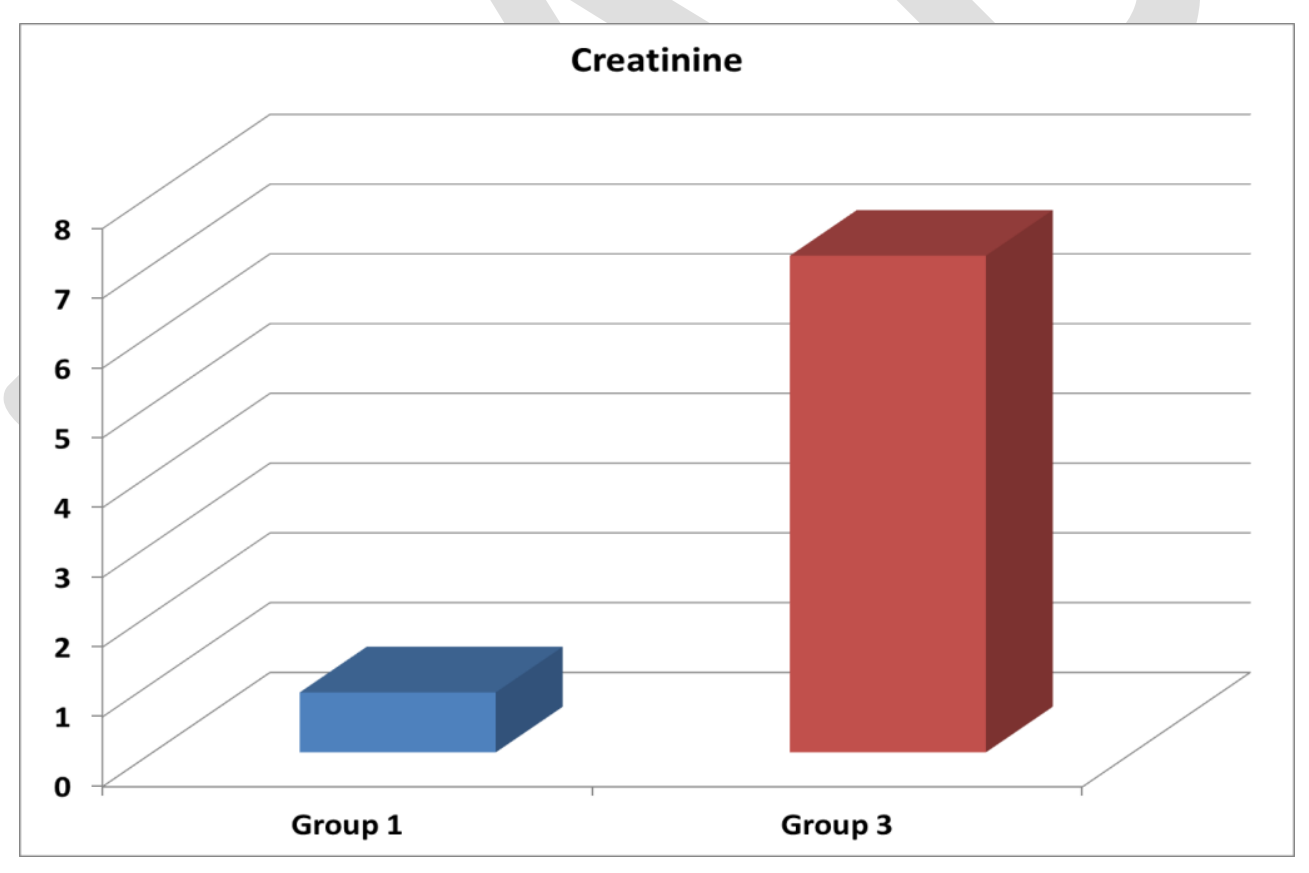

Figure (1) showed Comparison between group $1 \&$ 3as regarding to Creatinine 


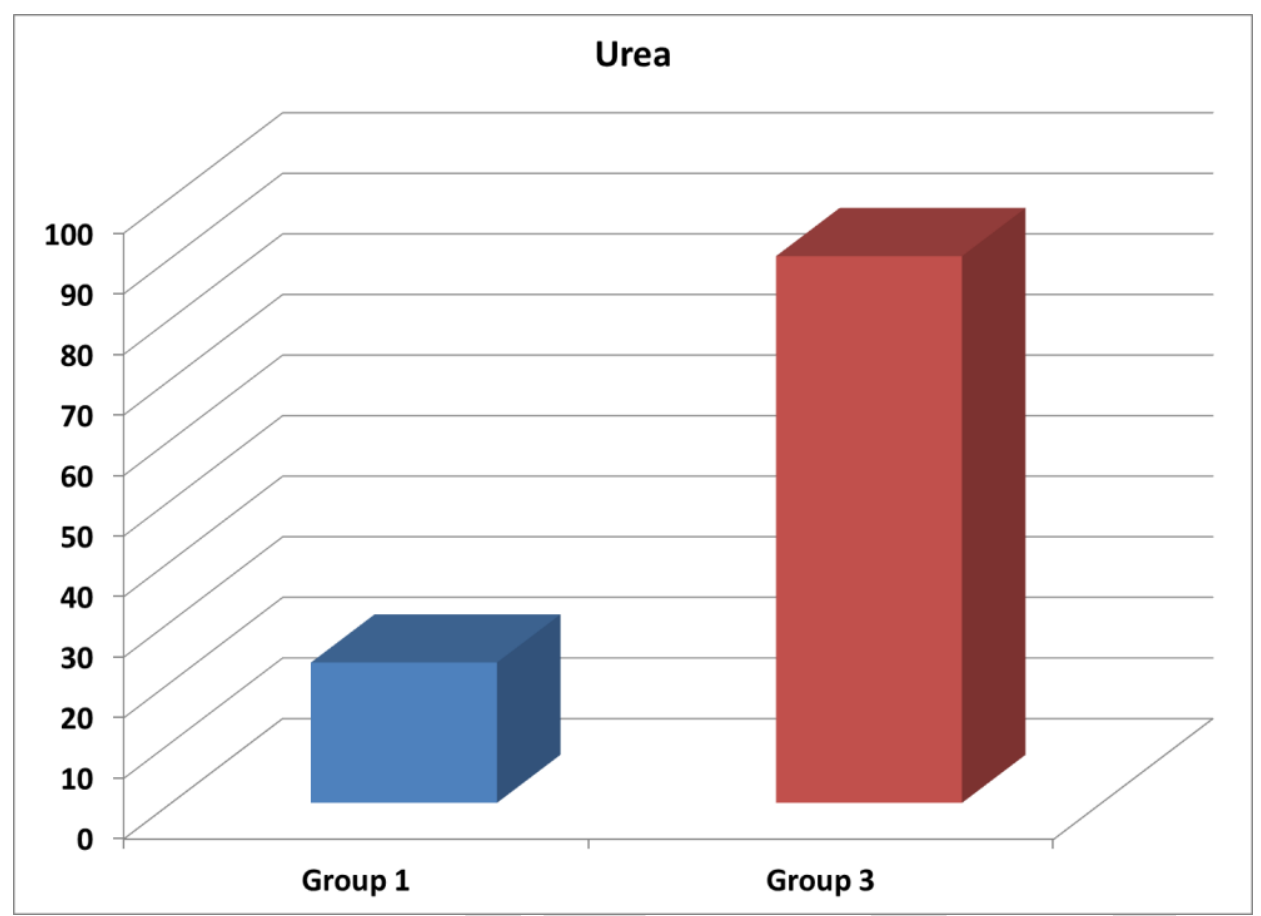

Figure (2) showed Comparison between group $1 \&$ 3as regarding to Urea

*Table (2) Comparison between group 2 and group 4 as regarding to Creatinine \& urea.

\begin{tabular}{||l|c|c|c|c|}
\hline Variables & $\begin{array}{c}\text { Group 2 } \\
(\mathrm{n}=12) \\
(\text { mean } \pm \mathrm{SD})\end{array}$ & $\begin{array}{c}\text { Group 4 } \\
(\mathrm{n}=12) \\
(\text { mean } \pm \mathrm{SD})\end{array}$ & t- value & p- value \\
\hline \hline Creatinine & $0.64 \pm 0.09$ & $8.98 \pm 2.21$ & 13.045 & $<0.001^{*}$ \\
\hline Urea & $21.08 \pm 1.16$ & $79.25 \pm 21.33$ & 9.431 & $<0.001^{*}$ \\
\hline
\end{tabular}

$* \mathrm{P}<0.05$ is considered Significant

Table (2) shows highly statistical significant difference between studied groups as regards serum creatinine \& Urea. 


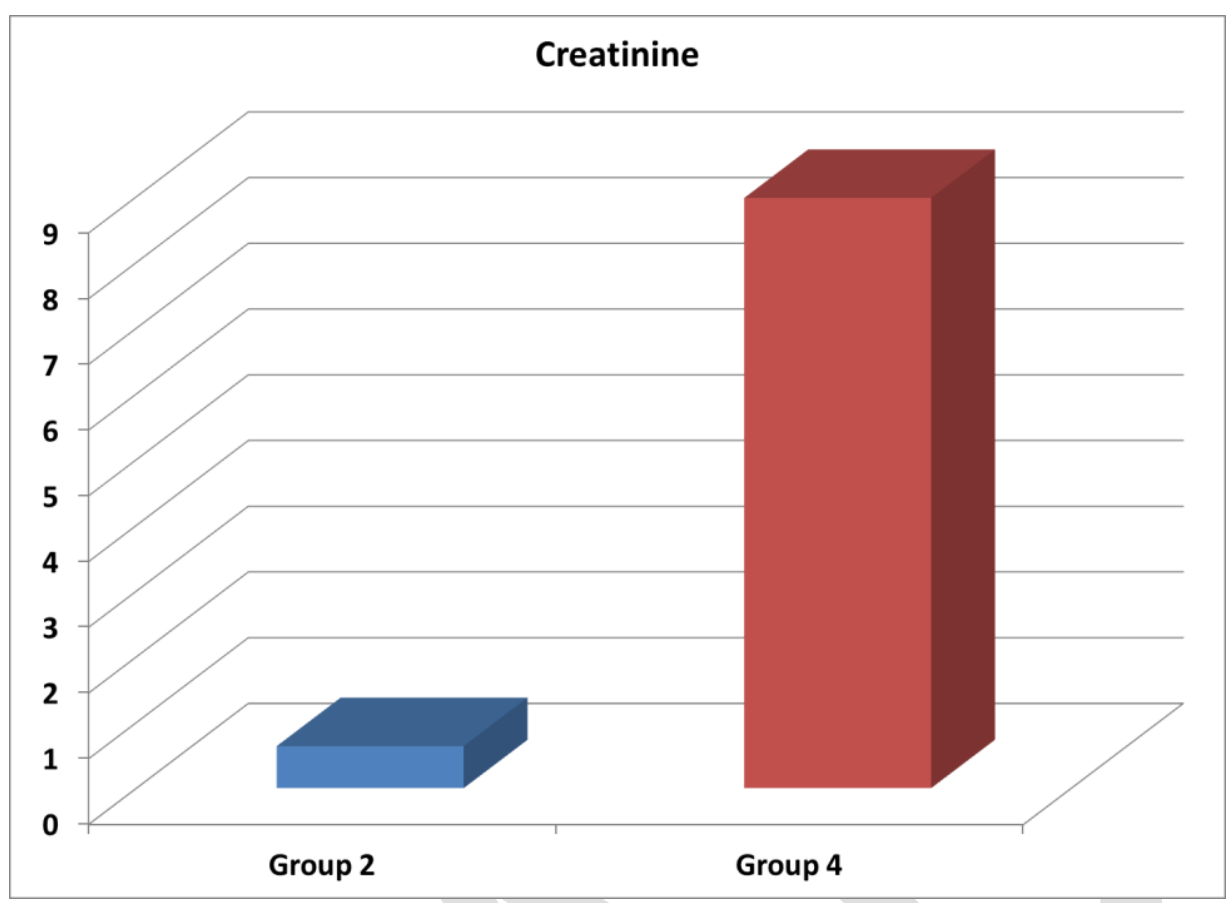

Figure (3) showed Comparison between group $2 \& 4$ as regarding to Creatinine

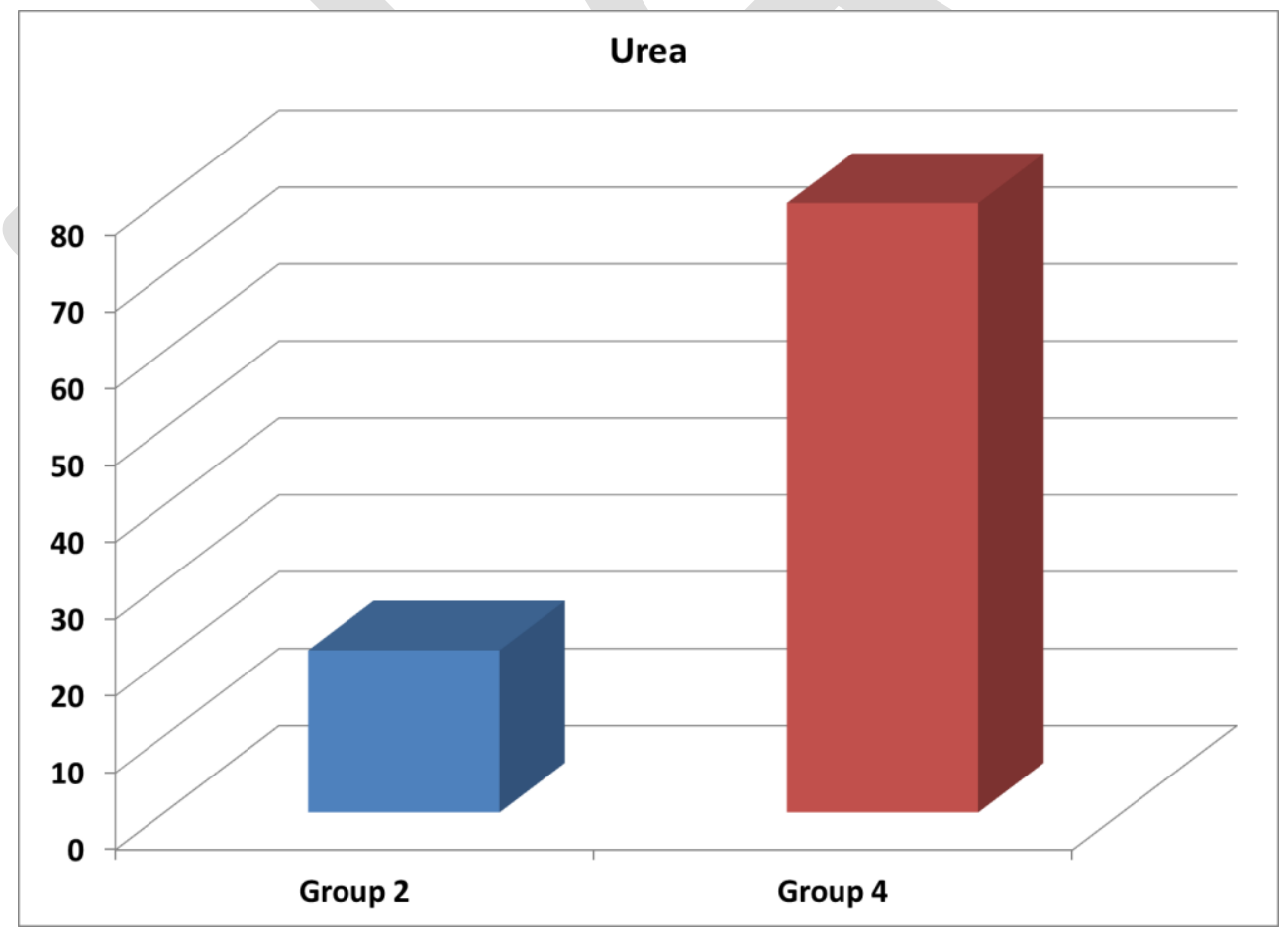

Figure (4) showed Comparison between group $2 \& 4$ as regarding to Urea 
*Table (3) Comparison between group 1 and group 3as regarding to Heamoglobin.

\begin{tabular}{||c|c|c|c|c||}
\hline \multirow{2}{*}{ Variables } & $\begin{array}{c}\text { Group1 } \\
(\mathrm{n}=12)\end{array}$ & $\begin{array}{c}\text { Group 3 } \\
(\mathrm{n}=12)\end{array}$ & t- value & $\mathrm{p}$ - value \\
& $($ mean $\pm \mathrm{SD})$ & $($ mean $\pm \mathrm{SD})$ & & \\
\hline \hline $\mathrm{Hb}$ & $12.55 \pm 1.25$ & $8.93 \pm 2.84$ & 4.038 & $0.001 *$ \\
\hline
\end{tabular}

$\mathrm{P}<0.05$ is considered Significant

Table (3) Shows Comparison between studied groups as regarding to Heamoglobin.

It was found that (group3) showed a significant decrease compared to (group1) $(\mathrm{p}<0.001)$.

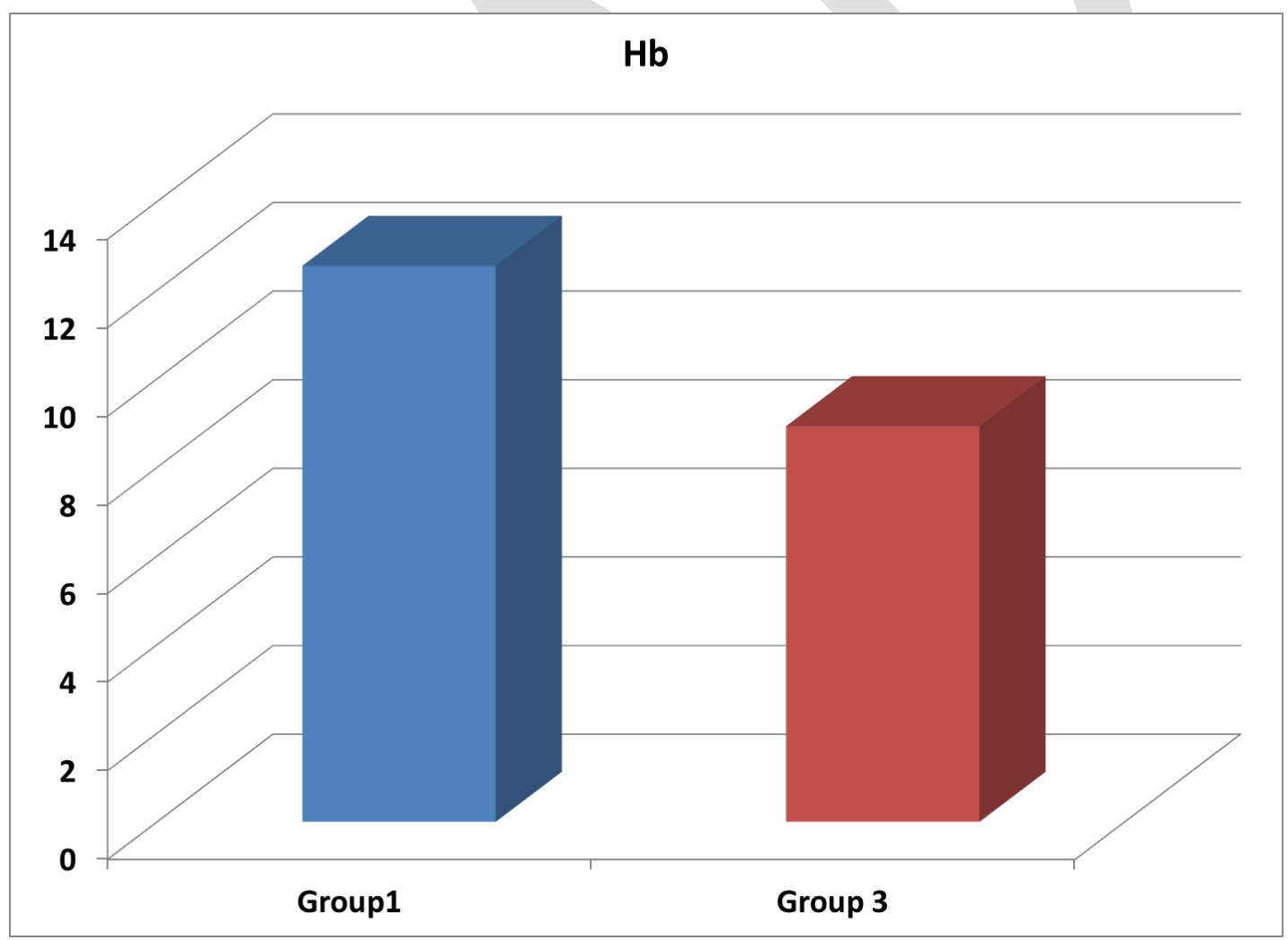

Figure (5) Comparison between group 1 and group 3as regarding to Heamoglobin.

*Table (4) Comparison between group 2 and group 4as regarding to Heamoglobin. 


\begin{tabular}{||c|c|c|c|c||}
\hline \multirow{2}{*}{ Variables } & $\begin{array}{c}\text { Group2 } \\
(\mathrm{n}=12) \\
(\mathrm{mean} \pm \mathrm{SD})\end{array}$ & $\begin{array}{c}\text { Group4 } \\
(\mathrm{n}=12) \\
(\mathrm{mean} \pm \mathrm{SD})\end{array}$ & t-value & $\mathrm{p}$ - value \\
\hline $\mathrm{Hb}$ & $12.44 \pm 0.60$ & $10.89 \pm 1.94$ & 2.643 & $0.020^{*}$ \\
\hline
\end{tabular}

$\mathrm{P}<0.05$ is considered Significant

Table (4) Shows Comparison between group 2 and group 4as regarding to Heamoglobin.

It was found that (group 4) showed a significant decrease compared to (group 2) $(\mathrm{p}<0.05)$.

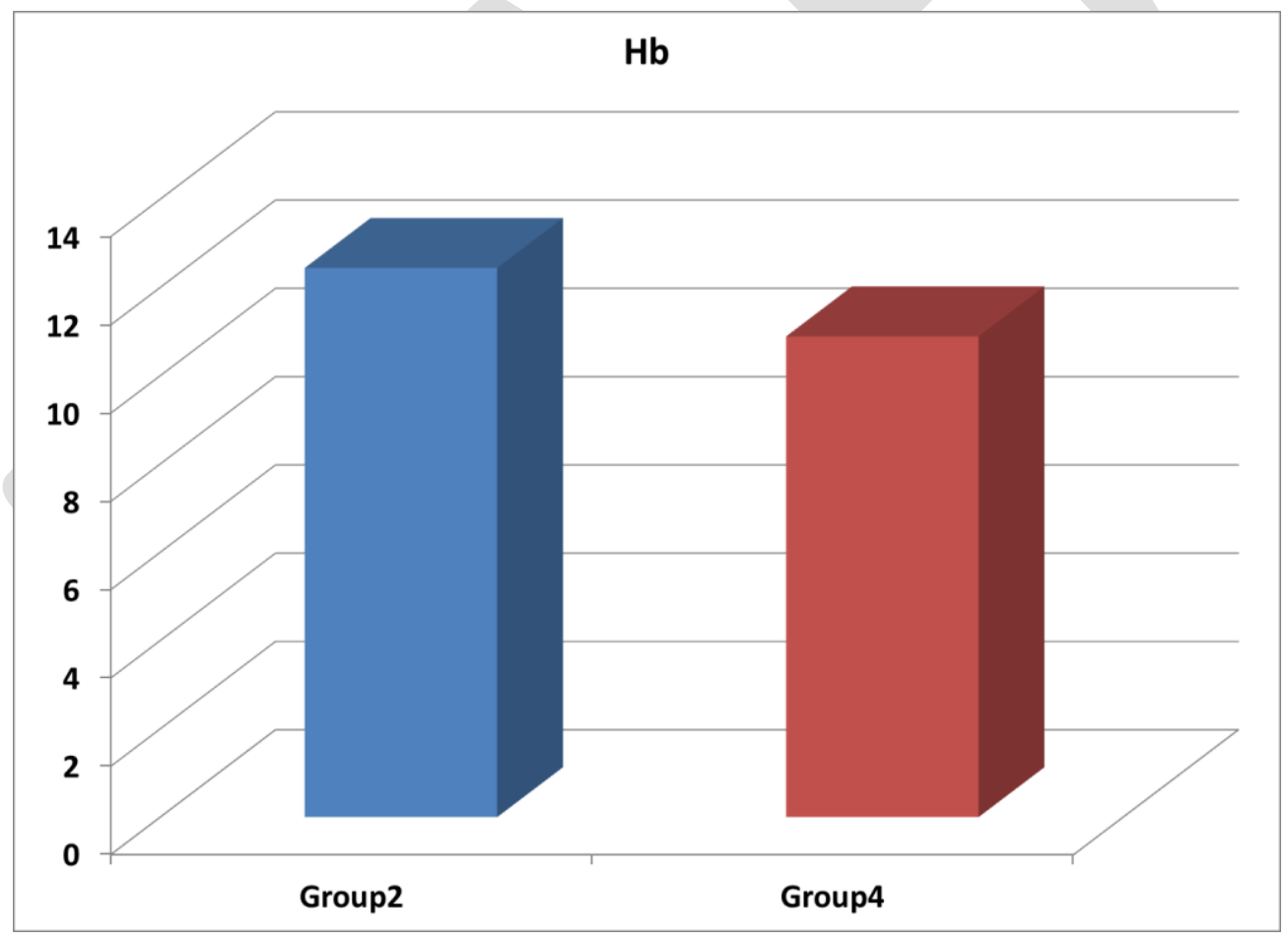

Figure (6) Comparison between group 2 and group 4 as regarding to Heamoglobin.

*Table (5) Comparison between group 1\& group 3 as regardingCD4 \& CD56 


\begin{tabular}{||l|c|c|c|c||}
\hline Variables & $\begin{array}{c}\text { Group 1 } \\
(\mathrm{n}=12) \\
(\text { mean } \pm \mathrm{SD})\end{array}$ & $\begin{array}{c}\text { Group 3 } \\
(\mathrm{n}=12) \\
(\text { mean } \pm \mathrm{SD})\end{array}$ & t- value & p- value \\
\hline \hline CD4 & $11.00 \pm 14.94$ & $0.16 \pm 0.26$ & 2.510 & $0.029 *$ \\
\hline CD56 & $27.87 \pm 10.47$ & $23.01 \pm 13.43$ & 0.989 & 0.334 \\
\hline
\end{tabular}

$\mathrm{P}<0.05$ is considered Significant

Table (5) Shows comparison between studied group as regarding CD4 \& CD56.

It was found that group (3) showed significant decrease compared to group 1.

Table (6): ROC curve for CD4 to compare patients versus control in adult cases (group 3 vs group 1)

\begin{tabular}{|c|c|}
\hline & CD4 \\
\hline Cut off point & 0.255 \\
\hline Area under the curve & 0.986 \\
\hline Sensitivity & $100 \%$ \\
\hline Specificity & $91.7 \%$ \\
\hline P Value & $<0.001 *$ \\
\hline
\end{tabular}




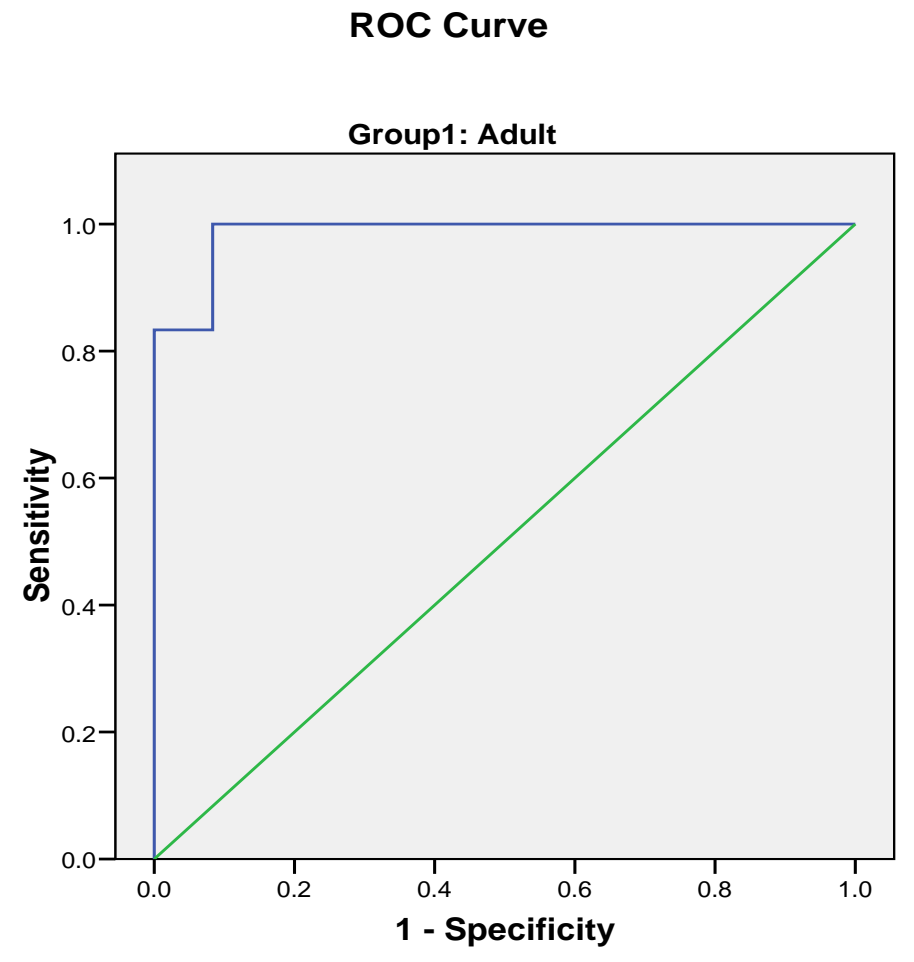

Figure (7): ROC curve for CD4(group 3 vs group 1)

Table (7): ROC curve for CD56 to compare patients versus control in adult cases (group 3 vs group 1)

\begin{tabular}{|c|c|}
\hline & CD56 \\
\hline Cut off point & 20.65 \\
\hline Area under the curve & 0.569 \\
\hline Sensitivity & $83.3 \%$ \\
\hline Specificity & $50 \%$ \\
\hline P Value & 0.564 \\
\hline
\end{tabular}




\section{ROC Curve}

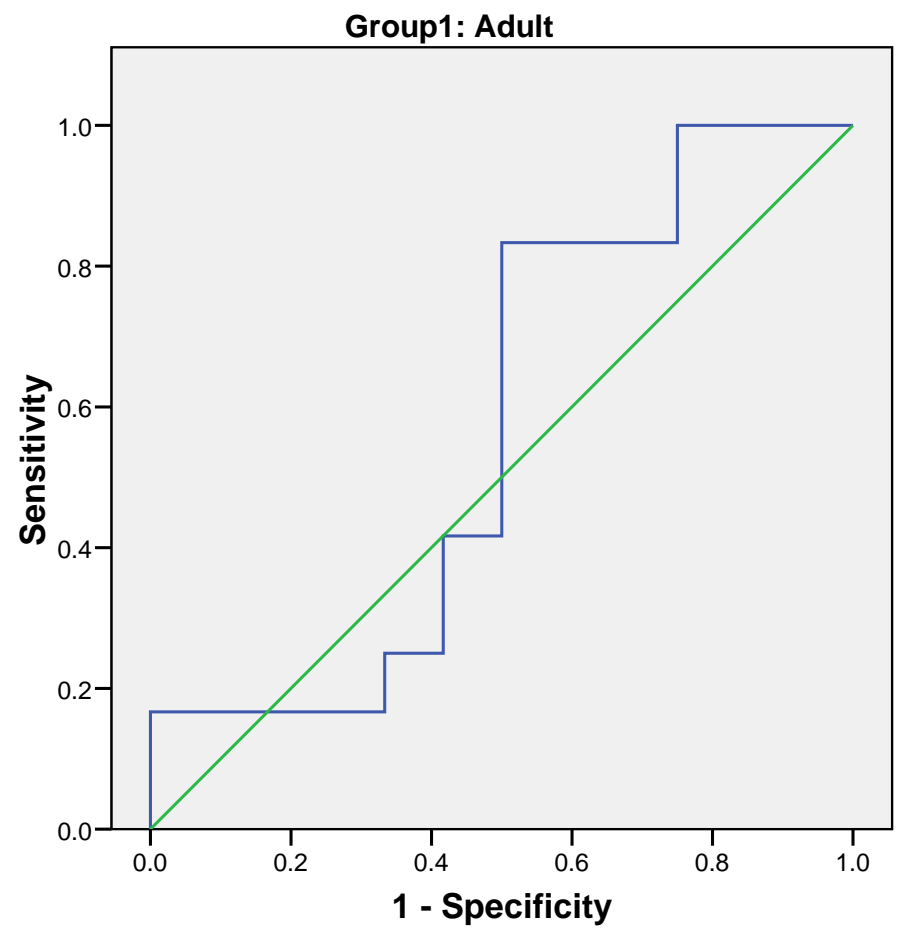

Figure (8): ROC curve for CD56 (group 3 vs group 1)

*Table(8): Comparison between group 2 \& group 4 as regardingCD4 \& CD56.

\begin{tabular}{||l|c|c|c|c||}
\hline Variables & $\begin{array}{c}\text { Group 2 } \\
(\mathrm{n}=12) \\
(\text { mean } \pm \mathrm{SD})\end{array}$ & $\begin{array}{c}\text { Group 4 } \\
(\mathrm{n}=12) \\
(\text { mean } \pm \mathrm{SD})\end{array}$ & t- value & p- value \\
\hline \hline CD4 & $7.10 \pm 4.65$ & $1.44 \pm 3.98$ & 3.197 & $0.004 *$ \\
\hline CD56 & $16.28 \pm 10.03$ & $8.77 \pm 4.61$ & 2.358 & $0.032^{*}$ \\
\hline
\end{tabular}

$\mathrm{P}<0.05$ is considered Significant 
Table (8) shows Comparison between studied group as regardingCD4 \& CD56.It was found that group (4) showed significant decrease compared to group(2).

Table (9): ROC curve for CD4 to compare patients versus control in child cases(Group 4 vs group 2)

\begin{tabular}{|l|c|}
\hline & CD4 \\
\hline Cut off point & 1.725 \\
\hline Area under the curve & 0.903 \\
\hline Sensitivity & $91.7 \%$ \\
\hline Specificity & $91.7 \%$ \\
\hline P Value & $0.001 *$ \\
\hline
\end{tabular}

\section{ROC Curve}

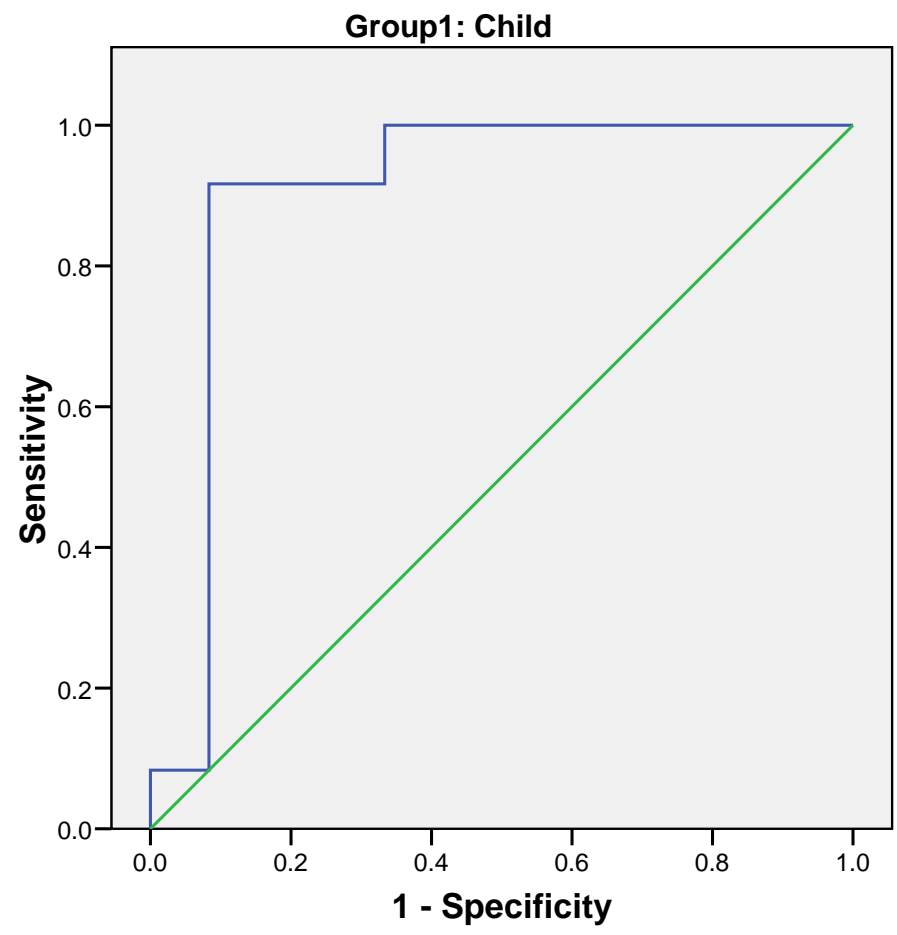

Figure (9): ROC curve for CD4 (group 4vs group 2) 
Table (10): ROC curve for CD56 to compare patients versus control in child cases (Group 4 vs group 2)

\begin{tabular}{|c|c|}
\hline & CD56 \\
\hline Cut off point & 15.455 \\
\hline Area under the curve & 0.708 \\
\hline Sensitivity & $50 \%$ \\
\hline Specificity & $100 \%$ \\
\hline P Value & 0.083 \\
\hline
\end{tabular}

ROC Curve

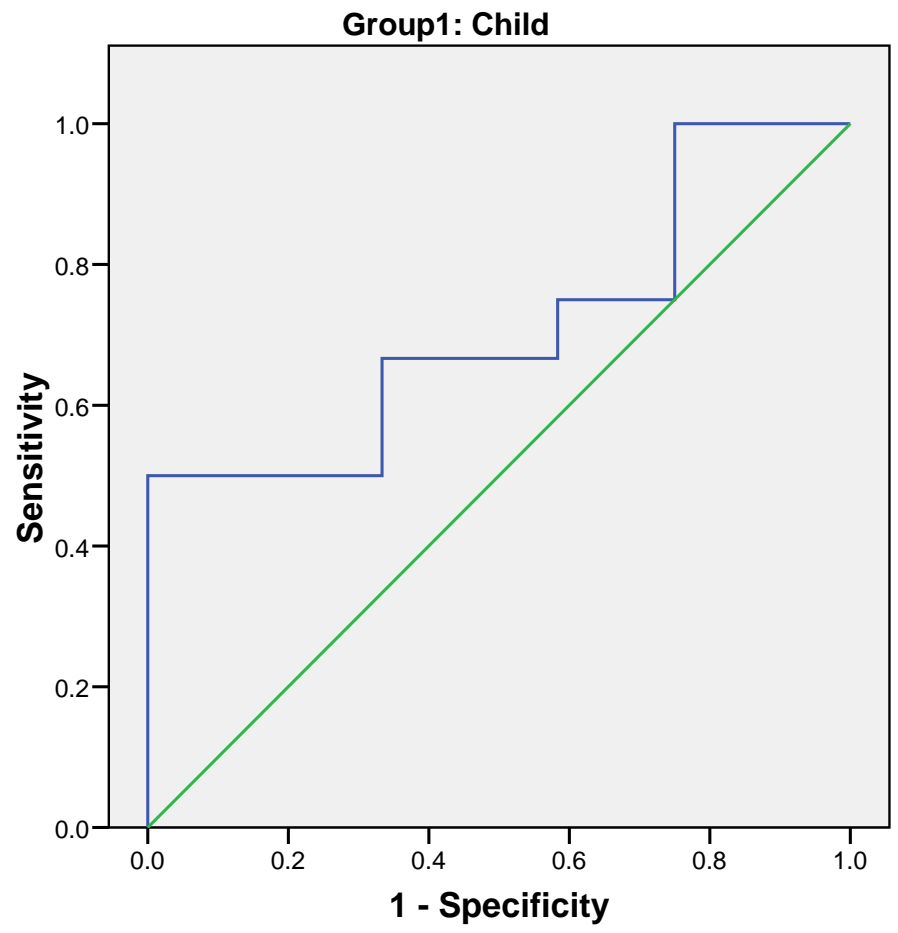

Figure (10): ROC curve for CD56 (group 4vs group 2)

\section{DISCUSSION}

Elevated serum creatinine concentration and Urea nitrogen regarded as sensitive indicator for patients with chronic Kidney Disease (ESRD). In this study, there was a statistically significant increase in serum creatinine concentration and Urea 
nitrogen in patients with Chronic Kidney Disease (ESRD) compared with healthy control groups (table 2,3) . This result came in agreement with (Girndt $M$ 1999) who reported that serum creatinine concentration and Urea nitrogen were significantly higher in the (ESRD) patients compared with control group.

In this study we find that blood heamoglobin is decreased in patients with chronic kidney disease (ESRD) compared with control groups with normal serum creatinine concentration and urea nitrogen (table 4,5) This result came in agreement with (Madeleine $\mathbf{V}$ 2010) who reported that blood heamoglobin significantly lower in (ESRD) compared with control groups.

In this study we find that CD4 is significant lower in patients with chronic kidney disease (ESRD) compared with control groups. This result came in agreement with (Hendrikx TK 2009) who observed lower number of CD4 and CD25 in end - stage renal disease patients especially in haemodialysis (HD), when compared to healthy controls. These results are very interesting since it has been demonstrated that these specific $T$

\section{CONCLUSION}

This study was focused on the evaluation of CD markers (CD4 \& CD56) in monocyte sub population of Egyptian children and adults with chronic renal failure under renal dialysis and correlate cell populations, also known as regulatory $\mathrm{T}$ cells (Treg), play a key role in the control of the immune system (Piccirillo CA 2008, Sakaguchi S et al., 2006).

Blood monocyte subpopulations have been defined in man initially, and the two major types of monocytes are the CD14+ CD16+ monocytes. These cells have been shown to exhibit distinct phenotype and function, and the CD14+ CD16+ were labeled proinflammatory based on higher expression of proinflammatory cytokines and higher potency in antigen presentation (Ziegler-Heitbrock, H. W. L 1988). Nockher (Nockher WA 2001) When following patients during hemodialysis, also noted a preferential depletion of CD14+ CD16+ monocytes in blood early on within the first hour of hemodialysis. A similar depletion was reported in patients on cardiopulmonary bypass, which involved exposure of blood to membranes in the oxygenator (Stefanou, D. C 2004). This came with agreement in this study where we found decrease in CD4 \& CD56 in patients with end-stage renal disease under (HD) compared to healthy controls .

with healthy groups .We find in this study that there is a significantly decrease in CD4 \& CD56 in most of children and adults with chronic renal failure under dialysis. 


\section{REFERENCES}

Bash LD, Erlinger TP, Coresh J, et al. Inflammation, hemostasis, and the risk of kidney function decline in the Atherosclerosis Risk in Communities (ARIC) Study. Am $J$

Kidney

Dis. Apr 2009;53(4):596-605.

Chang, J. K. C., NG, C. S. and HUI, P. K. (1988), A simple guide to the terminology and application of leucocyte monoclonal antibodies. Histopathology, 12: 461-480.

Choi AI, Rodriguez RA, Bacchetti P, et al. White/black racial differences in risk of end-stage renal disease and death. Am J Med. Jul 2009;122(7):672-8.

\section{Girndt M, Sester U, Sester M, et}

al. Impaired cellular immune function in patients with endstage renal failure. Nephrol Dial Transplant1999;14:2807-2810.

Madeleine V. Nephrol Dial Transplant (2010) 25: 205-212 . doi: 10.1093/ndt/gfp397 .

HCDM, responsible for HLDA workshop and CD molecules".
Human Cell Differentiation Molecules Council (successor to the HLDA Workshops). Retrieved 2009-06-01.

Hendrikx TK, End-stage renal failure and regulatory activities of CD4+CD25bright+FoxP3+ Tcells. Nephrol Dial Transplant 2009;24:1969-1978.

\section{Hsu CY, Ordoñez JD, Chertow GM, et}

al. The risk of acute renal failure in patients with chronic kidney disease. Kidney Int 2008; 74:101.

James MT, Hemmelgarn BR, Wiebe N, et al. Glomerular filtration rate, proteinuria, and the incidence and consequences of acute kidney injury: a cohort study. Lancet 2010; 376:2096.

Madeleine V. Nephrol Dial Transplant (2010) 25: 205-212 . doi: 10.1093/ndt/gfp397 .

Nockher WA, Wiemer J, Scherberich JE. Clin Exp Immunol. 2001 Jan;123(1):49-55. 
Piccirillo CA. Regulatory $\mathrm{T}$ cells in health and disease. Cytokine 2008;43:395-401.

Sakaguchi S, Ono M, Setoguchi R, et

al. Foxp3+ CD25+ CD4+ natural regulatory $\mathrm{T}$ cells in dominant self-tolerance and autoimmune disease. Immunol

Rev 2006;212:8-27.

Stefanou, D. C., Asimakopoulos, G., Yagnik, D. R., Haskard, D. O., Anderson, J. R., Philippidis, P., Landis, R. C., Taylor, K. M. (2004) Monocyte Fc $\gamma$ receptor expression in patients undergoing coronary artery bypass graftingAnn. Thorac.

Surg. 77,951-955
Ziegler-Heitbrock, H. W. L., Passlick, B., Flieger, D. (1988) The monoclonal antimonocyte antibody My4 stains B lymphocytes and two distinct monocyte subsets in human peripheral blood Hybridoma 7,521-527

Zola H, Swart B, Banham A, Barry S, Beare A, Bensussan A, Boumsell L, D Buckley C, Bühring HJ, Clark G, Engel P, Fox D, Jin BQ, Macardle PJ, Malavasi F, Mason D, Stockinger H, Yang X. (2007). "CD molecules 2006--human cell differentiation molecules.".JImmunol Methods 318 (1-2): $1-$ 5. doi:10.1016/j.jim.2006.11.001. PMID 17174972 